Article

\title{
Weather and Air Quality Drive the Winter Use of Utah's Big and Little Cottonwood Canyons
}

\author{
Hongchao Zhang and Jordan W. Smith * \\ Institute of Outdoor Recreation and Tourism and Department of Environment and Society, Utah State University, \\ Logan, UT 84322, USA; hongchao.zhang@aggiemail.usu.edu \\ * Correspondence: jordan.smith@usu.edu; Tel.: +1-435-830-6294
}

Received: 30 August 2018; Accepted: 3 October 2018; Published: 8 October 2018

check for

updates

\begin{abstract}
Winter outdoor recreation opportunities in Utah are directly impacted by the effects of climate change and deteriorating air quality. We examine the influences of daily weather conditions and air quality on winter use of two prominent Utah canyons located just outside Salt Lake City-Big and Little Cottonwood Canyons. Daily weather data were collected both within the canyons and in Salt Lake City; daily air quality data were collected for just Salt Lake City. We hypothesized that desirable weather within the canyons (i.e., cooler temperatures, more snowfall, and deeper snow depths) serves as a "pull" factor, positively influencing the volume of traffic. We also hypothesized that poor air quality within the city acts as a "push" factor on individuals' travel behavior, this too would positively influence the volume of traffic up the canyons. We used a panel time-series regression model to determine the influence of both these "push" and "pull" factors on use of the canyons during the winter months. Our results revealed that, as expected, cooler temperatures and greater amounts of snow in the canyons, as well as poorer air quality in the city, have a positive and significant influence on winter canyon use. These findings suggest that warmer winter temperatures, as well as deteriorating air quality in the city, may have substantial impacts on Utah's outdoor recreation economy.
\end{abstract}

Keywords: outdoor recreation; climate change; air quality; skiing; snowboarding

\section{Introduction}

Utah is world famous for its unique and exceptional winter weather conditions. The state's dry atmosphere and high-elevation canyons create optimal conditions for large snowfall events characterized by fluffy, deep powder. The state has capitalized on this resource, marketing itself to potential visitors as having the "Greatest Snow on Earth" [1,2]. The state's outstanding winter weather conditions support numerous world-class ski resorts, most of which are located within an hour's drive of Salt Lake City, the state's capital and most populous city. Since the mid-2000s the state's ski resorts have accommodated around four million skier days per season [3]. However, winter recreation opportunities within the state are at risk due to rising winter temperatures and more variable and infrequent snowfall events [1,2]. For example, during the 2014-2015 winter, warmer than average temperatures and less than average snowfall resulted in a 5.2\% drop in skier-days relative to the 2013-2014 winter [3]. Rising winter temperatures, coupled with more variable and infrequent snowfall events are projected to be the largest factor affecting the vitality of Utah's winter tourism economy $[4,5]$.

In addition to the effects of climate change, future winter outdoor recreation participation rates are also likely to be affected by deteriorating air quality in urban areas proximate to winter outdoor recreation destinations. This is certainly the case in Utah, where the majority of the state's population resides in the large valleys below the Wasatch Front mountain range. Ringed by mountains, these valleys experience inversion events in the winter in which the higher pressure of the atmosphere 
at high elevations traps cooler air, along with greenhouse gas emissions in the lower elevation valley bottoms. These inversion events often last for several days to multiple weeks at a time and can pose a major health risk to vulnerable populations [6]. Individuals who live in the valleys often seek respite from the poor air quality of the city by escaping to the higher elevations and to the cleaner air of nearby canyons. There is plenty of anecdotal evidence suggesting that a deterioration in urban air quality results in an increase in visitation to nearby winter outdoor recreation destinations [7]. However, there has been relatively little empirical research to document if, and to what extent, urban air quality affects visitation to nearby high-elevation outdoor recreation destinations.

In this research, we empirically examine how daily weather conditions and air quality affect visitation to two of Utah's most notable winter outdoor recreation destinations, the Big and Little Cottonwood Canyons. Specifically, the daily weather conditions and air quality measures we examine are characterized as either push- or pull-factors, simply implying that these factors either motivate individuals to move away from poor conditions in the city (push-factors) or move towards desirable conditions in the nearby canyons (pull-factors). Our analysis, which is focused on visitation to the Big and Little Cottonwood Canyons during the 2016-2017 winter, provides an empirically-grounded case-study of how both weather conditions and air quality affect visitation to winter outdoor recreation decisions.

\section{Literature Review}

\subsection{Push and Pull Factors Model}

The push-pull model introduced by Crompton [8] has been widely applied in tourism and recreation research $[9,10]$. The model distinguishes between factors that "push" tourists away from their home locations and those factors that "pull" tourists to visit a specific location. Push factors include undesirable characteristics of the tourists' home location, these can be environmental (e.g., poor weather conditions), social (e.g., traffic and/or crowding), and managerial (e.g., a lack of or poor quality recreation settings). How each of these push factors affects the tourists' travel behavior is fairly intuitive; however, many of the relationships have been supported by investigations into tourists' motivations [11]. Previous research has found evidence that poor environment quality at individuals' home locations does, in fact, significantly influence their travel behavior [12,13]. Poor climatic and environmental conditions will encourage people to escape from their home locations and visit more comfortable destinations. Additionally, unseasonably cold winter temperatures at individuals' home locations have been shown to have a significant push-type effect on their behavior, motivating them to travel to warmer destinations [14].

Pull-factors, conversely, are the environmental, social, and managerial characteristics of a destination that, if more desirable than the characteristics at individuals' home locations, are likely to influence those individuals to travel to the destination [9]. Like push-factors, the mechanistic way that pull-factors affect travel behavior is fairly intuitive and logical. In winter recreation destinations, like Utah's Cottonwood Canyons, previous research has found the total snow depth at a destination and daily snowfall amounts are both significant pull-factors exhibiting a positive influence on visitation [15-17]. Previous research has also found that daily snowfall not only has a positive influence on visitation the day of the snowfall event, but also several days after the event [16].

\subsection{Weather's Effect on Travel Behavior}

Weather is one of the defining attributes of tourism destinations. It determines the attractiveness, comfort, and suitability of the destination for nearly all outdoor recreation and tourist activities [7]. Winter weather conditions can significantly impact both the supply and demand for winter recreation such as skiing and snowboarding [15-18]. Recently, Steiger et al. [19] conducted a critical review of the literature on how climate change will impact ski tourism. The review revealed the scientific literature has shown evidence for projected decreased reliability of slopes dependent on natural snow, increased 
snowmaking requirements, shortened and more variable ski seasons, a contraction in the number of operating ski areas, altered competitiveness among and within regional ski markets, and attendant implications for ski tourism employment and values of vacation property. The literature has specifically found specific winter weather conditions to have a significant influence on individuals' travel behavior; these conditions are summarized in Table 1.

Table 1. The key weather variables related to winter recreation.

\begin{tabular}{|c|c|c|}
\hline Variables & References & Findings \\
\hline Snow Depth & {$[15,16,20-22]$} & $\begin{array}{l}\text { A positive relationship between skiing demand and good } \\
\text { snow conditions. }\end{array}$ \\
\hline Temperature & {$[15-18,20,23,24]$} & $\begin{array}{l}\text { Average temperature increases the demand for skiing on a daily } \\
\text { basis but can decrease demand over long periods of time. }\end{array}$ \\
\hline Daily Snowfall at Ski Resorts & {$[16,17,25-28]$} & Daily snowfall at ski resorts has a positive impact on ski visits. \\
\hline Daily Snowfall in Nearby Urban Areas & {$[16,27]$} & $\begin{array}{l}\text { Some support for a "backyard hypothesis", that snowfall in } \\
\text { urban areas increases the demand for skiing at nearby resorts. }\end{array}$ \\
\hline
\end{tabular}

Snow depth has been the most consistently significant variable influencing individuals' travel behavior [15,16,20-22]. Töglhofer et al. [15] found a positive relationship between the number of overnight stays at ski resorts and the snow depth at those resorts by using time series data from 1972 to 2007 of 185 ski areas in Austria. Similarly, both Dawson and Scott [29] as well as Falk [20] found the snow depth of a destination does have a positive influence on travel behavior, but that the effect is not present at high elevations ( $>2000 \mathrm{~m}$ ). The limiting factor of elevation likely comes from the fact that resorts at higher elevations tend to have longer ski seasons, allowing them to accommodate winter outdoor recreationists later in the season after snow depth levels begin to decline and resorts at lower elevations begin to wind down their operations for the year.

Temperature is another factor that significantly impacts individuals' winter travel behavior $[15-18,23,24,30]$. However, the directionality of the influence of temperature on individuals' winter travel behavior has been mixed. Falk [30] found that colder winter weather was associated with an increase in overnight stays at ski resorts. However, both Shih et al. [23] and Hamilton et al. [16] found a negative relationship between the temperatures at winter recreation destinations and visitation. The study by Töglhofer et al. [15] found no clear evidence for a consistent influence of temperature on individuals' winter travel behavior.

Snowfall at winter recreation destinations and nearby urban areas has also been shown to influence individuals' winter travel behavior $[16,17,27]$. For example, ski resorts in New Hampshire and Vermont accommodated about three-quarters of a million fewer visitors in three years with the lowest snowfall relative to the average observed between 1984 to 2001 [16,27]. Similarly, Hamilton et al. [16] found daily snowfall at winter recreation destinations as well as daily snowfall in nearby urban areas throughout the New England region of the U.S. was positively and significantly related to visitation at those destinations. Several studies conducted outside the U.S. have also found a strong and positive relationship between snowfall at winter recreation destinations and visitation to those destinations [25, 26,28].

\subsection{Air Quality and Winter Recreation}

Poor winter air quality is common for the residents of Salt Lake City [31]. The mountainous terrain of Northern Utah provides the not-so-ideal geographic conditions that trap anthropogenic emissions from vehicles, houses, and factories [32]. Winter air quality is worst during inversion events, prolonged periods of time in which the high-altitude atmospheric pressures stagnate, prohibiting the emissions trapped at lower altitudes from escaping. During these events, air quality levels within the city often exceed federal standards [6], subsequently affecting the health of residents [33]. Poor air quality within the city provides a strong "push" motivation for people to escape from their homes and head to the nearby high-elevation canyons where the air quality is much better [33]. Evidence for this push-factor not only comes from observations of daily life in Salt Lake City, but empirical evidence has 
also shown that poor air quality has a significant influence on the amount of outbound travel from urban centers [13]. Collectively, the anecdotal and empirical evidence suggests that the poor air quality in Salt Lake City will lead to the increased use of high-elevation recreation settings in nearby canyons.

\subsection{Study Objectives}

Previous research has provided a fundamental knowledge about how winter weather and air quality affect individuals' travel behavior (Table 1). However, no previous research has incorporated both weather and air quality conditions into an investigation of winter travel behavior. This study fills this gap in the literature by empirically examining how daily weather conditions and air quality affect visitation to two of Utah's most notable winter outdoor recreation destinations during the 2016-2017 winter.

\section{Methods}

\subsection{Study Area}

Our investigation focuses on two canyons adjacent to Salt Lake City, Utah (USA). Salt Lake City has received an annual average of $119.38 \mathrm{~cm}$ (47 inches) of snowfall over the past 30 years [34]. This snowfall, combined with cold winter temperatures (between $-3{ }^{\circ} \mathrm{C}$ to $6{ }^{\circ} \mathrm{C}$ ), support exceptional conditions for winter outdoor recreation activities such as downhill skiing and snowboarding. Salt Lake City itself sits on the west side of the Wasatch Mountain range which extends for approximately $250 \mathrm{~km}$ from the Utah-Idaho border through central Utah. Nearly all winter outdoor recreation activities for the 1 million residents who live in the Salt Lake Valley occurs within in the canyons of the Wasatch Mountains [35]. Our investigation focuses specifically on the Big and Little Cottonwood Canyons, both of which are located about 20 min away from downtown Salt Lake City and are easily accessible by highway (Figure 1). Big Cottonwood Canyon is home to two world-class ski resorts (Solitude and Brighton), both are popular among skiers and snowboarders. The base elevation of the Solitude resort is $2435 \mathrm{~m}$; the highest point is $3059 \mathrm{~m}$. The base elevation of the Brighton resort is $2669 \mathrm{~m}$; the highest point is $3280 \mathrm{~m}$. Big Cottonwood Canyon is also known for its legendary rock-climbing routes, epic backcountry skiing access, hiking and mountain biking trails, and picnic areas. The canyon is accessed by the terminal Big Cottonwood Canyon Scenic Byway (SR-190). The byway only allows through-travel to Park City during summer months, with the canyon pass not being plowed in the winter months. Like Big Cottonwood Canyon, Little Cottonwood is home for two ski resorts (Snowbird and Alta). The base elevation of Snowbird is $2365 \mathrm{~m}$; the highest point is $3353 \mathrm{~m}$. The base elevation of Alta is $2600 \mathrm{~m}$; the highest point is $3216 \mathrm{~m}$. Little Cottonwood Canyon can only be accessed via Little Cottonwood Canyon Road which terminates at the Alta ski resort. 


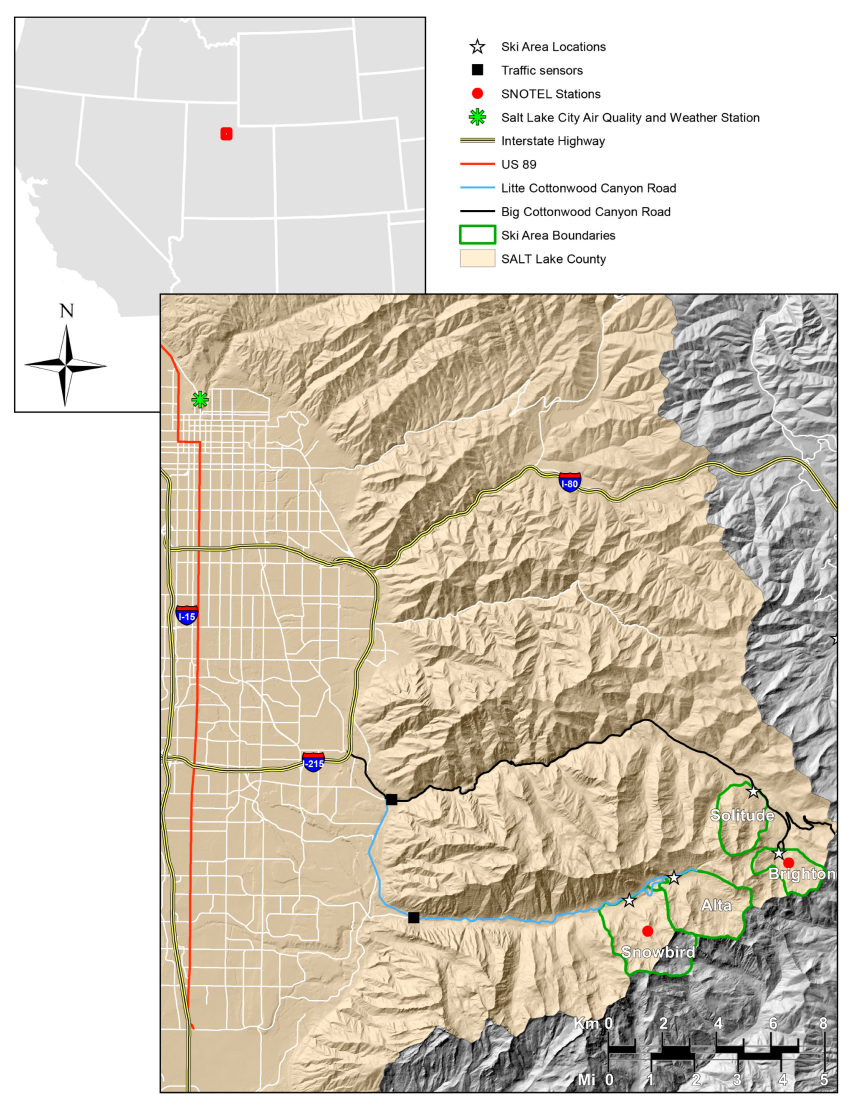

Figure 1. The study area.

\subsection{Data Collection}

We obtained daily traffic, weather, and air quality data from various U.S. federal and state agencies for the winter of 2016-2017. We defined the winter season as 1 November 2016, through 30 April 2017.

\subsection{Measures}

\subsubsection{Inbound Traffic Data to the Big and Little Cottonwood Canyons}

Daily traffic data consisted of inbound traffic counts collected at the mouths of both canyons via induction sensors; we acquired these data from the Utah Department of Transportation (UDOT) [36]. The inbound traffic count data serve as the dependent variable in our statistical model.

\subsubsection{Weather Variables}

We collected the daily average temperature, snowfall, and snow depth data for Salt Lake City as well as both the Big and Little Cottonwood Canyons; these data were collected from the U.S. Snowpack Telemetry Data Repository (SNOTEL) and the National Oceanic and Atmospheric Administration (NOAA) [37,38]. Weather data for Salt Lake City came from the Salt Lake City International Airport (\#USW00024127) NOAA station, while weather data for the Big and Little Cottonwood Canyons came from the Brighton (\#366) and Snowbird (\#766) SNOTEL stations, respectively. Approximately fifty percent of the weather data were missing from the SNOTEL stations. Where weather data were missing, we imputed that data using the nearest non-SNOTEL weather station (Brighton: \#USS0011J57S; Snowbird: \#USS0011J42S). These imputed data were obtained from the Utah Climate Center and the National Oceanic and Atmospheric Administration (NOAA) [38].

Table 2 shows the descriptive statistics for each weather variable. During the winter of 2016-2017, the mean daily average temperature of Salt Lake City was $4.78{ }^{\circ} \mathrm{C}$ with a range from $-14.44{ }^{\circ} \mathrm{C}$ to $18.89^{\circ} \mathrm{C}$. Salt Lake City received an average of $1.09 \mathrm{~cm}$ of snow per day, resulting in an average snow 
depth of $6.81 \mathrm{~cm}$. In Little Cottonwood Canyon, the mean daily average temperature was $-5.78^{\circ} \mathrm{C}$ with a range from $-25^{\circ} \mathrm{C}$ to $10^{\circ} \mathrm{C}$; the mean daily snowfall was $4.88 \mathrm{~cm}$ with a daily average snow depth of $195.25 \mathrm{~cm}$. In Big Cottonwood Canyon, the mean daily average temperature was $-1.61^{\circ} \mathrm{C}$ with a range from $-17.22{ }^{\circ} \mathrm{C}$ to $10^{\circ} \mathrm{C}$; the average daily snowfall was $4.34 \mathrm{~cm}$ while the average snow depth was $123.70 \mathrm{~cm}$.

Table 2. The descriptive statistics.

\begin{tabular}{|c|c|c|c|c|c|}
\hline \multirow[t]{3}{*}{ Variables } & \multicolumn{5}{|c|}{ Location } \\
\hline & \multicolumn{5}{|c|}{ Little Cottonwood Canyon } \\
\hline & Mean & $\mathrm{N}$ & SD & Min & Max \\
\hline Inbound_Traffic (count) & 3713 & 162 & 1478 & 873 & 7260 \\
\hline Air_Temperature_Average_Canyons $\left({ }^{\circ} \mathrm{C}\right)$ & -5.78 & 79 & -8.22 & -25.00 & 10.00 \\
\hline Snowfall_Canyons $(\mathrm{cm})$ & 4.88 & 181 & 9.35 & 0.00 & 45.72 \\
\hline One_Pre_Day_Snowfall_Canyons (cm) & 4.90 & 181 & 9.37 & 0.00 & 45.72 \\
\hline Two_Pre_Day_Snowfall_Canyons (cm) & 4.93 & 181 & 9.40 & 0.00 & 45.72 \\
\hline \multirow[t]{3}{*}{ Snow_Depth_Canyons $(\mathrm{cm})$} & 195.25 & 181 & 109.32 & 0.00 & 347.98 \\
\hline & \multicolumn{5}{|c|}{ Big Cottonwood Canyon } \\
\hline & Mean & $\mathrm{N}$ & SD & Min & Max \\
\hline Inbound_Traffic (count) & 2719 & 176 & 1153 & 738 & 5525 \\
\hline Air_Temperature_Average_Canyons $\left({ }^{\circ} \mathrm{C}\right)$ & -1.61 & 180 & -12.07 & -17.22 & 10.00 \\
\hline Snowfall_Canyons $(\mathrm{cm})$ & 4.34 & 179 & 13.74 & 0.00 & 162.56 \\
\hline One_Pre_Day_Snowfall_Canyons (cm) & 4.34 & 179 & 13.74 & 0.00 & 162.56 \\
\hline Two_Pre_Day_Snowfall_Canyons (cm) & 4.32 & 179 & 13.74 & 0.00 & 162.56 \\
\hline \multirow[t]{3}{*}{ Snow_Depth_Canyons $(\mathrm{cm})$} & 123.70 & 180 & 66.52 & 0.00 & 233.68 \\
\hline & \multicolumn{5}{|c|}{ Salt Lake City } \\
\hline & Mean & $\mathrm{N}$ & SD & Min & Max \\
\hline $\mathrm{PM}_{2.5}\left(\mu \mathrm{g} / \mathrm{m}^{3}\right)$ & 7.98 & 156 & 8.93 & 1.00 & 46 \\
\hline Ozone (ppm) & 0.04 & 141 & 0.01 & 0.10 & 0.06 \\
\hline Air_Temperature_Average_SLC $\left({ }^{\circ} \mathrm{C}\right)$ & 4.78 & 140 & -10.89 & -14.44 & 18.89 \\
\hline Snowfall_SLC $(\mathrm{cm})$ & 1.09 & 140 & 3.10 & 0.00 & 19.81 \\
\hline One_Pre_Day_Snowfall_SLC (cm) & 1.09 & 140 & 3.10 & 0.00 & 20.32 \\
\hline Two_Pre_Day_Snowfall_SLC (cm) & 1.09 & 140 & 3.10 & 0.00 & 20.32 \\
\hline
\end{tabular}

Beyond calculating the basic statistics for each original weather variable, we also generated two lagged variables: snowfall on the previous day, and snowfall two-days before. This was done because the previous days' snowfall has been found to be a significant factor affecting winter ski resort visitation [16].

\subsubsection{Air Quality Index (AQI)}

Daily air quality data ( $\mathrm{PM}_{2.5}$ and Ozone) for Salt Lake City (no air quality data were available for either Big or Little Cottonwood Canyons) were collected from the Utah Department of Environmental Quality [39] and the U.S. Environmental Protection Agency (USEPA) [40]. $\mathrm{PM}_{2.5}$ refers to particulate matter with a diameter of $2.5 \mu \mathrm{m}$ or less. These fine particulates are created by a variety of sources including power plants, motor vehicles, airplanes, residential wood burning, and dust storms. We transformed the raw air quality data to AQI using Equations (1) and (2) [41]. Following the U.S. Environmental Protection Agency's AQI breakpoints (Table 3) for $\mathrm{PM}_{2.5}$ and Ozone, the data were coded into three categories (good, moderate, and unhealthy for sensitive groups).

$$
A Q I_{P M 2.5}=\left[\frac{\left(P M_{o b s}-P M_{\min }\right) \times\left(A Q I_{\max }-A Q I_{\min }\right)}{\left(P M_{\max }-P M_{\min }\right)}\right]+A Q I_{\min }
$$




$$
A Q I_{\text {Ozone }}=\left[\frac{\left(\text { Ozone }_{\text {obs }}-\text { Ozone }_{\min }\right) \times\left(A Q I_{\text {max }}-A Q I_{\text {min }}\right)}{\left(\text { Ozone }_{\max }-\text { Ozone }_{\min }\right)}\right]+A Q I_{\min }
$$

Table 3. The U.S. Environmental Protection Agency Air Quality Index breakpoints.

\begin{tabular}{ccc}
\hline Air Quality Index Categories: Index Value & Ozone (ppm) & $\mathbf{P M}_{\mathbf{2 . 5}}\left(\boldsymbol{\mu g} / \mathbf{m}^{\mathbf{3}}\right)$ \\
\hline Good (up to 50) & $0-0.054$ & $0-12$ \\
Moderate (51-100) & $0.055-0.070$ & $12.1-35.4$ \\
Unhealthy for Sensitive Groups (101-150) & $0.071-0.085$ & $35.5-55.4$ \\
\hline
\end{tabular}

Descriptive statistics for Salt Lake City's Ozone, $\mathrm{PM}_{2.5}$, and the AQI for the 2016-2017 winter are presented in Table 4. Average daily $\mathrm{PM}_{2.5}$ levels for Salt Lake City were $7.98 \mu \mathrm{g} / \mathrm{m}^{3}$ with a range between $1 \mu \mathrm{g} / \mathrm{m}^{3}$ to $46 \mu \mathrm{g} / \mathrm{m}^{3}$. Based on the U.S. EPA's AQI breakpoints, 128 days were classified as good, 22 days were classified as moderate, and 6 days were classified as unhealthy for the sensitive group. The Average Ozone levels were $0.04 \mathrm{ppm}$ with a range between $0.01 \mathrm{ppm}$ to $0.06 \mathrm{ppm}$. Again, according to U.S. EPA's AQI breakpoints, 135 days were classified as good and 6 days were classified as moderate. There were no days classified as unhealthy for the sensitive group.

Table 4. The descriptive statistics of Salt Lake City's air quality for the 2016-2017 winter.

\begin{tabular}{lcc}
\hline Air Quality Measures and Categories & N & Percentage of Winter Days \\
\hline AQI_Cat_PM 2.5 & 156 & 100 \\
Good & 128 & 82.1 \\
Moderate & 22 & 14.1 \\
Unhealthy for Sensitive Group & 6 & 3.8 \\
AQI_Cat_Ozone & 141 & 100 \\
Good & 135 & 95.7 \\
Moderate & 6 & 4.3 \\
Unhealthy for Sensitive Group & 0 & 0 \\
\hline
\end{tabular}

\subsection{Analysis}

After inspecting the distribution (i.e., skewness and kurtosis) of the daily inbound traffic data and determining it was indeed normal (skewness $=0.601$, kurtosis $=-0.214$ ), we opted to use a panel time-series regression model to examine the influences of the daily weather conditions and air quality on daily traffic entering both Big and Little Cottonwood Canyons during the 2016-2017 winter. Panel time-series regression models are appropriate for data consisting of multiple observations (days) across a sample of units (canyons). Our final data set consisted of 181 observations (days) across 2 units of observation (canyons). Given that the number of observations is greater than the number of units of observation, the data comprise what is referred to as a macropanel [42]. The dependent variable in the regression model was the inbound traffic count at both Big and Little Cottonwood Canyons. The independent variables included:

- the weather conditions for the two canyons and Salt Lake City;

- the air quality of Salt Lake City; and

- a dummy variable corresponding to whether the day was a weekend or a weekday.

The model was fit using the xtreg command in Stata 14.2.

Prior to estimation, we checked for highly correlated $(r>0.30)$ independent variables using Pearson correlation coefficients; this was done to avoid multicollinearity and subsequently, biased estimates. We also examined the correlation of each independent variable and the inbound traffic count to assess which independent variables were most likely to be significantly related to inbound winter traffic. The final statistical model was iteratively constructed by adding individual independent variables into the model in descending order of their absolute correlation with inbound winter traffic. 
No independent variables that were highly correlated with those already in the statistical model were added to avoid multicollinearity and retain the model's parsimony. The final model was fit using a panel time-series specification with each canyon serving as a unique 'panel'. The model consisted of six independent variables and is specified as

$$
\begin{gathered}
+\beta_{2} A Q I \_C a t \_P M 2.5 \_S L C_{i} \\
+\beta_{3} \text { Air_Temperature_Average_Canyons }{ }_{i j} \\
+\beta_{4} \text { Snow_Depth_Canyons } i j \\
+\beta_{5} \text { One_Pre_Day_Snowfall_SLC } C_{i} \\
+\beta_{6} \text { Two_Pre_Day_Snowfall_Canyons } i j+v_{i}+\epsilon_{i j}
\end{gathered}
$$

The subscripts $i$ and $j$ refer to each day and each panel (i.e., canyon) respectively. Panel time-series models include a composed error term, denoted as $v_{i}+\epsilon_{i j}$. Estimates were derived using a generalized least squares fixed-effects estimator [43]. The fixed-effects estimator allows for arbitrary dependence between the observed effects and any unobserved effect associated with each panel [44]. This is a relaxation of the assumption of independence associated with the random-effects model. More importantly, the dependence is logical in our case, given the effects of the independent variables on inbound traffic may vary systematically between the two canyons.

\section{Results}

Results from the panel time-series model are presented in Table 5. The model explained two-thirds of the variance in winter canyon use $\left(R^{2}=0.657\right)$. The model suggests that weekend days, weather conditions, and air quality $\left(\mathrm{PM}_{2.5}\right)$ have a significant impact on winter canyon use. Specifically, weekend days were significantly and positively related to canyon use (Coef. $=1340.5 ; p<0.001$ ).

Table 5. The panel time-series model results estimating the influence of weather conditions and air quality on inbound traffic to the Big and Little Cottonwood Canyons during the 2016-2017 winter.

\begin{tabular}{lccc}
\hline \multicolumn{1}{c}{ Model } & Coef. & Robust S.E. & Sig. \\
\hline (Constant) & 1359.4 & 226.5 & $<0.001$ \\
Weekend & 1340.5 & 112.5 & $<0.001$ \\
AQI_Cat_PM $2.5 \_S L C$ & 363.3 & 103.1 & 0.001 \\
Air_Temperature_Average_Canyons & -16.9 & 4.7 & $<0.001$ \\
Snow_Depth_Canyons & 19.3 & 1.9 & $<0.001$ \\
One_Pre_Day_Snowfall_SLC & -22.8 & 59.3 & 0.701 \\
Two_Pre_Day_Snowfall_Canyons & -6.4 & 19.1 & 0.737 \\
Overall $R^{2}=0.657 ; \sigma \_u=456.8 ; \sigma \_\varepsilon=695.0$ & & & \\
\hline
\end{tabular}

Most of the weather variables were significantly related to inbound traffic. First, the daily average temperature within the canyons was significantly and negatively related to canyon use (Coef. $=-16.9$; $p<0.001)$. Warmer temperatures in the canyons resulted in fewer inbound trips, as would be expected. Specifically, a $1^{\circ} \mathrm{F}$ increase in temperature in the canyons was associated with approximately 17 fewer inbound trips per day. Secondly, snow depths in the canyons was also significantly, but positively, related to inbound traffic (Coef. $=19.3 ; p<0.001)$. Deeper snow packs are associated with more inbound trips; this too was expected. A 1-inch increase in snow depth in the canyons was associated with approximately 19 more inbound trips per day. Neither snowfall on the previous day in Salt Lake City nor snowfall in the canyons two-days prior had a significant effect on winter canyon use. Finally, the daily air quality index $\left(\mathrm{PM}_{2.5}\right)$ of Salt Lake City was significantly and positively related to winter canyon use (Coef. $=363.3 ; p=0.001$ ). Poorer air quality in the city results in more trips being taken up the canyon; again, this was expected. As the air quality in Salt Lake City moved from either "good" to "moderate" or from "moderate" to "unhealthy for sensitive groups", inbound traffic increased by approximately 363 trips per day. 


\section{Discussion}

Rising winter temperatures, along with more variable and infrequent snowfall events, may have a devastating impact on the winter outdoor recreation opportunities within Utah. Previous research from a variety of other geographic locations has shown that as temperatures rise, and snowfall events become less frequent, visitation to ski resorts decline. Subsequently, there is the very real possibility that prominent winter outdoor recreation destinations may not remain economically viable unless they offer a broader suite of non-snow-dependent on-site activities to attract visitors [45]. The analysis we have presented here certainly suggests that this may be the case for winter outdoor recreation destinations in Utah as well. Data from the 2016-2017 winter reveal that visitation to two of the state's most prominent canyons is heavily dependent upon favorable weather conditions (i.e., cooler days with deeper snow depths). In the coming years, as winter temperatures continue to rise, and average daily snow depths continue to decline, the quality of winter outdoor recreation opportunities available to residents and tourists will concomitantly decline. The four winter resorts in our study area may be able to mitigate the negative impacts of a warming climate through artificial snowmaking; all four have extensive snowmaking operations that are heavily utilized in low-snow years. Previous research has found snow-making to be a key way that winter ski resorts have been able to remain economically-viable despite poor winter weather conditions $[24,28,46]$. However, these studies also have found that snowmaking is only a short-term mitigation action and that it will not be a viable proposition for winter resorts beyond the middle of the 21st century, once the average daily low temperatures during the winter at many ski resorts exceeds $0{ }^{\circ} \mathrm{C}\left(32{ }^{\circ} \mathrm{F}\right)$.

The results of our study not only support the strong mechanistic linkages between the desirable pull-factors at winter outdoor recreation destinations and individuals' travel behavior, they also highlight the previously un-investigated linkages between the undesirable push factors of nearby urban areas and visitation to winter outdoor recreation destinations. Specifically, we found that poorer air quality in Salt Lake City was significantly and positively related to the volume of traffic headed up both Big and Little Cottonwood Canyons. These findings are not likely to be surprising to anyone familiar with winter inversion events, but to our knowledge, they are the first to empirically illustrate a relationship between the air quality in urban areas and use levels at nearby winter outdoor recreation destinations.

The Utah state government and the region's tourism interests are clearly aware that poor air quality has a detrimental effect on the residents' quality of life as well as the quality of experiences offered to tourists. For example, the state's legislature recently passed a bill providing residents who own wood burning stoves a $\$ 3800$ USD rebate to convert over to propane or natural gas furnaces [47]. Incentives like this are certainly needed, and the state government should be applauded for their efforts to improve the air quality during the winter months. However, should these efforts be ineffective or short-lived, it is likely, based upon our findings, that more and more residents and tourists will continue to flock to the higher-elevation canyons where the air is clearer. Winter outdoor recreation destinations in the canyons should be aware of this and anticipate visitation rates to increase as air quality in the city diminishes.

Like all research, this study does have limitations. First, because we used inbound traffic counts as our dependent variable, we were unable to differentiate between local outdoor recreationists and tourists. Being unable to differentiate between the two types of users is not critical, and most likely only weakens the statistical power of our model. This is because tourists who travel longer distances are less likely to be as sensitive as local visitors to less favorable weather conditions. Individuals traveling longer distances are more likely to be on set itineraries established many months in advance of their actual trip. Consequently, they will be more likely to ski and snowboard regardless of warm temperatures and poor snow conditions. Second, our study only utilized data from the winter of 2016-2017, the relatively small sample size is not sufficient for explaining the long-term effects of climate change and deteriorating air quality on winter visitation to Big and Little Cottonwood Canyons. Future research is needed to utilize data collected across numerous winter seasons to study 
the relationship between gradual shifts in climate and air quality and winter canyon visitation. Finally, our study was focused on just two canyons adjacent to Salt Lake City; this limited spatial scale restricts our ability to make inferences to a large suite of ski resorts. Future work on a larger spatial scale is needed.

Residents and visitors to Salt Lake City who recreate in the canyons adjacent to the city are likely attracted to the state because of its famous powdery deep snow. This study clearly supports this assumption, as we found the desirable pull factors of cooler winter days and deeper snow depth were positively related with the volume of traffic entering both Big and Little Cottonwood Canyons. However, it is not just the pristine mountain environment that draws people up to higher elevations. It is also due, in part, to a desire to escape (or be pushed away) from the poor air quality in the valley below. Our investigation also revealed that poor air quality in Salt Lake City had a significant influence on canyon use. Collectively, these findings suggest the future of winter outdoor recreation under climate change should not be thought of as a simple linear process of degraded environments leading to poorer-quality outdoor recreation opportunities. While that mechanistic relationship is certainly present, the future of winter outdoor recreation is also affected by confounding factors like the air quality at nearby urban centers. As air quality continues to diminish, visitation to nearby high-elevation winter outdoor recreation destinations is likely to increase. The future of winter outdoor recreation is more complex than often thought. As our investigation demonstrates, it is subject to dynamic push and pull factors that can affect participation in contradictory ways.

Author Contributions: Conceptualization, H.Z. and J.W.S.; Methodology, H.Z. and J.W.S.; Formal analysis, H.Z. and J.W.S.; Data Curation, H.Z.; Writing-original draft preparation, H.Z.; Writing-review and editing, J.W.S.; Visualization, H.Z.

Funding: This research was funded by the Institute of Outdoor Recreation and Tourism at Utah State University.

Acknowledgments: The authors are thankful for data provided by the Utah Department of Environmental Quality, the Utah Department of Transportation, the Natural Resources Conservation Service, the USU Climate Center, and the Environmental Protection Agency.

Conflicts of Interest: The authors declare no conflict of interest.

\section{References}

1. Steenburgh, W.J. Secrets of the Greatest Snow on Earth: Weather, Climate Change, and Finding Deep Powder in Utah's Wasatch Mountains and around the World; Utah State University Press: Logan, UT, USA, 2014.

2. Steenburgh, W.J.; Alcott, T.I. Secrets of the "greatest snow on earth". Bull. Am. Meteorol. Soc. 2008, 89, $1285-1294$. [CrossRef]

3. Leaver, J. The State of Utah's Travel and Tourism Industry. Available online: http://gardner.utah.edu/wpcontent/uploads / 2018TourismReport.pdf (accessed on 4 October 2018).

4. Hagenstad, M.; Burakowski, E.; Hill, R. The Economic Contributions of Winter Sports in a Changing Climate. Available online: https:/ / gzg764m8173gtwxg366onn13-wpengine.netdna-ssl.com/wp-content/uploads / 2018/02/POW_2018_economic_report-1.pdf (accessed on 4 October 2018).

5. Chapagain, B.P.; Poudyal, N.C.; Bowker, J.M.; Askew, A.E.; English, D.B.K.; Hodges, D.G. Potential effects of climate on downhill skiing and snowboarding demand and value at U.S. national forests. J. Park Recreat. Adm. 2018, 36, 75-96. [CrossRef]

6. Annual Report 2017: Division of Air Quality; Utah Department of Environmental Quality: Salt Lake City, UT, USA, 2017; pp. 1-55.

7. Gallarza, M.G.; Saura, I.G.; García, H.C. Destination image: Towards a Conceptual Framework. Ann. Tour. Res. 2002, 29, 56-78. [CrossRef]

8. Crompton, J.L. Motivations for pleasure vacation. Ann. Tour. Res. 1979, 6, 408-424. [CrossRef]

9. Bansal, H.; Eiselt, H.A. Exploratory research of tourist motivations and planning. Tour. Manag. 2004, 25, 387-396. [CrossRef]

10. Hamilton, J.M.; Maddison, D.J.; Tol, R.S.J. Climate change and international tourism: A simulation study. Glob. Environ. Chang. 2005, 15, 253-266. [CrossRef] 
11. You, X.; O’Leary, J.; Morrison, A.; Hong, G.-S. A cross-cultural comparison of travel push and pull factors. Int. J. Hosp. Tour. Adm. 2000, 1, 1-26. [CrossRef]

12. Nicholls, S. Climate change, tourism and outdoor recreation in Europe. Manag. Leis. 2006, 11, 151-163. [CrossRef]

13. Wang, L.; Fang, B.; Law, R. Effect of air quality in the place of origin on outbound tourism demand: Disposable income as a moderator. Tour. Manag. 2018, 68, 152-161. [CrossRef]

14. Hamilton, J.M.; Maddison, D.J.; Tol, R.S.J. Effects of climate change on international tourism. Clim. Res. 2005, 29, 245-254. [CrossRef]

15. Töglhofer, C.; Eigner, F.; Prettenthaler, F. Impacts of snow conditions on tourism demand in Austrian ski areas. Clim. Res. 2011, 46,1-14. [CrossRef]

16. Hamilton, L.C.; Brown, C.; Keim, B.D. Ski areas, weather and climate: Time series models for New England case studies. Int. J. Climatol. 2007, 27, 2113-2124. [CrossRef]

17. Holmgren, M.A.; McCracken, V.A. What affects demand for "the greatest snow on Earth?". J. Hosp. Mark. Manag. 2014, 23, 1-20. [CrossRef]

18. Smith, J.W.; Seekamp, E.; McCreary, A.; Davenport, M.; Kanazawa, M.; Holmberg, K.; Wilson, B.; Nieber, J. Shifting demand for winter outdoor recreation along the North Shore of Lake Superior under variable rates of climate change: A finite-mixture modeling approach. Ecol. Econ. 2016, 123, 1-13. [CrossRef]

19. Steiger, R.; Scott, D.; Abegg, B.; Pons, M.; Aall, C. A critical review of climate change risk for ski tourism. Curr. Issues Tour. 2017, 1-37. [CrossRef]

20. Falk, M. A dynamic panel data analysis of snow depth and winter tourism. Tour. Manag. 2010, 31, 912-924. [CrossRef]

21. Englin, J.; Moeltner, K. The value of snowfall to skiers and boarders. Environ. Resour. Econ. 2004, 29, $123-136$. [CrossRef]

22. Ozcelebi, O.; Demiroglu, O.C.; Kučerová, J. Snow reliability and climate elasticity: Case of a Slovak ski resort. Tour. Rev. 2015, 70, 1-12. [CrossRef]

23. Shih, C.; Nicholls, S.; Holecek, D.F. Impact of weather on downhill ski lift ticket sales. J. Travel Res. 2009, 47, 359-372. [CrossRef]

24. Scott, D.; Dawson, J.; Jones, B. Climate change vulnerability of the US Northeast winter recreation-tourism sector. Mitig. Adapt. Strateg. Glob. Chang. 2008, 13, 577-596. [CrossRef]

25. Elsasser, H.; Bürki, R. Climate change as a threat to tourism in the Alps. Clim. Res. 2002, 20, 253-257. [CrossRef]

26. Fukushima, T.; Kureha, M.; Ozaki, N.; Fujimori, Y.; Harasawa, H. Influences of air temperature change on leisure industries: Case study of ski activities. Mitig. Adapt. Strateg. Glob. Chang. 2002, 7, 173-189. [CrossRef]

27. Palm, B.T. Skiing with Climate Change: An Analysis of Climate Change and the Consequences for the Ski Industry in New Hampshire and Vermont. Ph.D. Thesis, Oxford University, Oxford, UK, 2001.

28. Scott, D.; McBoyle, G.; Mills, B. Climate change and the skiing industry in southern Ontario (Canada): Exploring the importance of snowmaking as a technical adaptation. Clim. Res. 2003, 23, 171-181. [CrossRef]

29. Dawson, J.; Scott, D. Managing for climate change in the alpine ski sector. Tour. Manag. 2013, 35, $244-254$. [CrossRef]

30. Falk, M. Impact of long-term weather on domestic and foreign winter tourism demand. Int. J. Tour. Res. 2013, 15, 1-17. [CrossRef]

31. Tribby, C.P.; Miller, H.J.; Song, Y.; Smith, K.R. Do air quality alerts reduce traffic? An analysis of traffic data from the Salt Lake City metropolitan area, Utah, USA. Transp. Policy 2013, 30, 173-185. [CrossRef]

32. Lareau, N.P.; Crosman, E.; Whiteman, C.D.; Horel, J.D.; Hoch, S.W.; Brown, W.O.J.; Horst, T.W. The persistent cold-air pool study. Bull. Am. Meteorol. Soc. 2012, 94, 51-63. [CrossRef]

33. Best, A. Winter Inversions Foul Salt Lake Valley. Available online: http:/ / mountaintownnews.net/2013/02/ 04/winter-inversions-foul-salt-lake-valley/ (accessed on 4 October 2018).

34. U.S. Climate Data. Salt Lake City Weather Averages. Available online: https://www.usclimatedata.com/ climate/salt-lake-city/utah/united-states/usut0225 (accessed on 30 August 2018).

35. Lamborn, C.C.; Burr, S.W. An Estimation of Visitor Use in Little Cottonwood, Big Cottonwood, and Millcreek Canyons. Available online: https://saveourcanyons.files.wordpress.com/2018/01/tri_canyon_visitor_use_ estimate.pdf (accessed on 4 October 2018).

36. Utah Department of Transportation. Traffic Statistics. Available online: https://www.udot.utah.gov/main/ f?p=100:pg::::1:T,V:507 (accessed on 30 August 2018). 
37. USDA Natural Resources Conservation Service. Snow Water Equivalent (SWE) and Snow Depth Data. Available online: https:/ / www.wcc.nrcs.usda.gov/snow/snotel-wedata.html (accessed on 30 August 2018).

38. National Oceanic and Atmospheric Administration. Land-Based Station Data. Available online: https: / / www.ncdc.noaa.gov/data-access/land-based-station-data (accessed on 30 August 2018).

39. Utah Department of Environmental Quality. Salt Lake County-Current Conditions. Available online: https: / / air.utah.gov / currentconditions.php?id=slc (accessed on 30 August 2018).

40. OAR U.S. Environ Air Data: Air Quality Data Collected at Outdoor Monitors across the US. Available online: https: / / www.epa.gov / outdoor-air-quality-data (accessed on 30 August 2018).

41. U.S. Environmental Protection Agency. Technical Assistance Document for the Reporting of Daily Air Quality—The Air Quality Index (AQI). Available online: https:/ / airnowtest.epa.gov/sites/default/files / 2018-09/aqi-technical-assistance-document-sept-2018_0.pdf (accessed on 4 October 2018).

42. Burdisso, T.; Sangiácomo, M. Panel time series: Review of the methodological evolution. Stata J. 2016, 16, 424-442.

43. Wooldridge, J.M. Introductory Econometrics: A Modern Approach, 6th ed.; Cengage: Boston, MA, USA, 2016; ISBN 0-324-58162-9.

44. Wooldridge, J.M. Basic linear unobserved effects panel data model. In Econometric Analysis of cross Section and Panel Data; MIT Press: Cambridge, MA, USA, 2010; pp. 281-343.

45. Alber, K.; Allamandola, M.A.; Balbi, S.; Bausch, T.; Benati, A.; Bonzanigo, L.; Cetara, L. ClimAlpTour-Climate Change and Its Impact on Tourism in the Alpine Space; Final Project Report of the Alpine Space Interreg Project ClimAlpTour; Založba ZRC: Ljubljana, Slovenia, 2011.

46. Wolfsegger, C.; Gössling, S.; Scott, D. Climate change risk appraisal in the Austrian ski industry. Tour. Rev. Int. 2008, 12, 13-23. [CrossRef]

47. Utah Department of Environmental Quality. Wood Stove Conversion Assistance Program. Available online: https: / / deq.utah.gov / air-quality / wood-stove-conversion-assistance-program (accessed on 30 august 2018).

(C) 2018 by the authors. Licensee MDPI, Basel, Switzerland. This article is an open access article distributed under the terms and conditions of the Creative Commons Attribution (CC BY) license (http:/ / creativecommons.org/licenses/by/4.0/). 